\title{
Insect Pollinator Fauna of Apricot from Gilgit-Baltistan, Pakistan
}

\author{
Hina Maryam¹, Muhammad Ather Rafi², Ahmed Zia', Ghulam Rasul ${ }^{3}$, Muhammad Kamal Sheikh ${ }^{3 *}$, \\ Muhammad Qasim ${ }^{4}$ and Gulnaz Parveen ${ }^{5}$
}

${ }^{1}$ National Insect Museum, National Agriculture Research Center, Islamabad, Pakistan; ${ }^{2}$ University of Swabi, Swabi, Khyber Pakbtunkbwa, Pakistan; ${ }^{3}$ Planning and Development Division, Pakistan Agricultural Research Council, Pakistan; ${ }^{4}$ Department of Entomology, Faculty of Agriculture, University of the Poonch, Rawalakot, Azad Jammu and Kashmir, Pakistan; ${ }^{5}$ Department of Botany, Women University, Swabi, Khyber Pakhtunkbwa, Pakistan.

Abstract | Surveys were conducted for apricot insect pollinators during apricot blossom period (early March) from Gilgit, Ghizer, Hunza-Nagar and Skardu. Total 18 species of 14 genera under seven families of orders Diptera, Hymenoptera and Lepidoptera were identified. Order Diptera was represented by family Syrphidae with four species under three genera. Order Hymenoptera represented four families i.e. Apidae with six species under four genera; Halictidae with two species under two genera; Megachilidae with one species under one genus; and Vespidae with three species under two genera. While order Lepidoptera was represented by two families, Nymphalidae and Papilionidae with single species in each family respectively. Two species namely, Scaeva selenitica of family Syrphidae and Xylocopa acutipennis of family Apidae are new records for Pakistan.

Received | January 25, 2019; Accepted | April 20, 2019; Published | April 17, 2020

*Correspondence | Muhammad Kamal Sheikh, Planning and Development Division, Pakistan Agricultural Research Council, Pakistan; Email: dmkamal@yahoo.com

Citation | Maryam, H., M.A. Rafi, A. Zia, G. Rasul, M.K. Sheikh, M. Qasim and G. Parveen. 2020. Insect pollinator fauna of apricot from Gilgit-Baltistan, Pakistan. Pakistan Journal of Agricultural Research, 33(2): 202-211.

DOI | http://dx.doi.org/10.17582/journal.pjar/2020/33.2.202.211

Keywords | Insect Pollinator, Apricot, Pollination, Gilgit-Baltistan, Pakistan

\section{Introduction}

$\mathrm{F}$ lowering plants depend wholly or partially on pollination for sexual reproduction (Klein et al., 2007). Over three quarters of the world's crops and more than 80 percent of all flowering plants are dependent on pollination (Kenmore and Krell, 1998). Majority of plants from which human beings benefit depend on arthropods as pollinators. Among arthropods, insects are important pollinator of crops worldwide. Without arthropods as pollinators, many plants could not set seed and reproduce fruits and without visit to plants, many arthropods population could crash (Ollerton, 1999). Recently the production value of pollinated crops in Pakistan was enumerated as 1.59 billion US\$ with major share of fruits with 0.98 billion US $\$$ (Irshad et al., 2014).

Apricot (Prunus armeniaca L.) is an imperative fruit crop of the Rosaceae family. During last two decades, apricot production has increased more than $85 \%$, mostly due to the increase in planting area in Algeria Egypt, Iran, Morocco, Pakistan, Turkey, and Uzbekistan (Bendif et al., 2017). In Pakistan, apricot is grown in Balochistan, Parachinar, Hangu, Chitral, Swat, Hazara Abbottabad, Murree, Northern Kashmir and Diamer, Gilgit, Ghanche, Ghizer, and Skardu districts of Gilgit-Baltistan. Along other deciduous fruits, apricot is primarily produced as cash crop in Gilgit- Baltistan, where apricot June 2020 | Volume 33 | Issue 2 | Page 202 


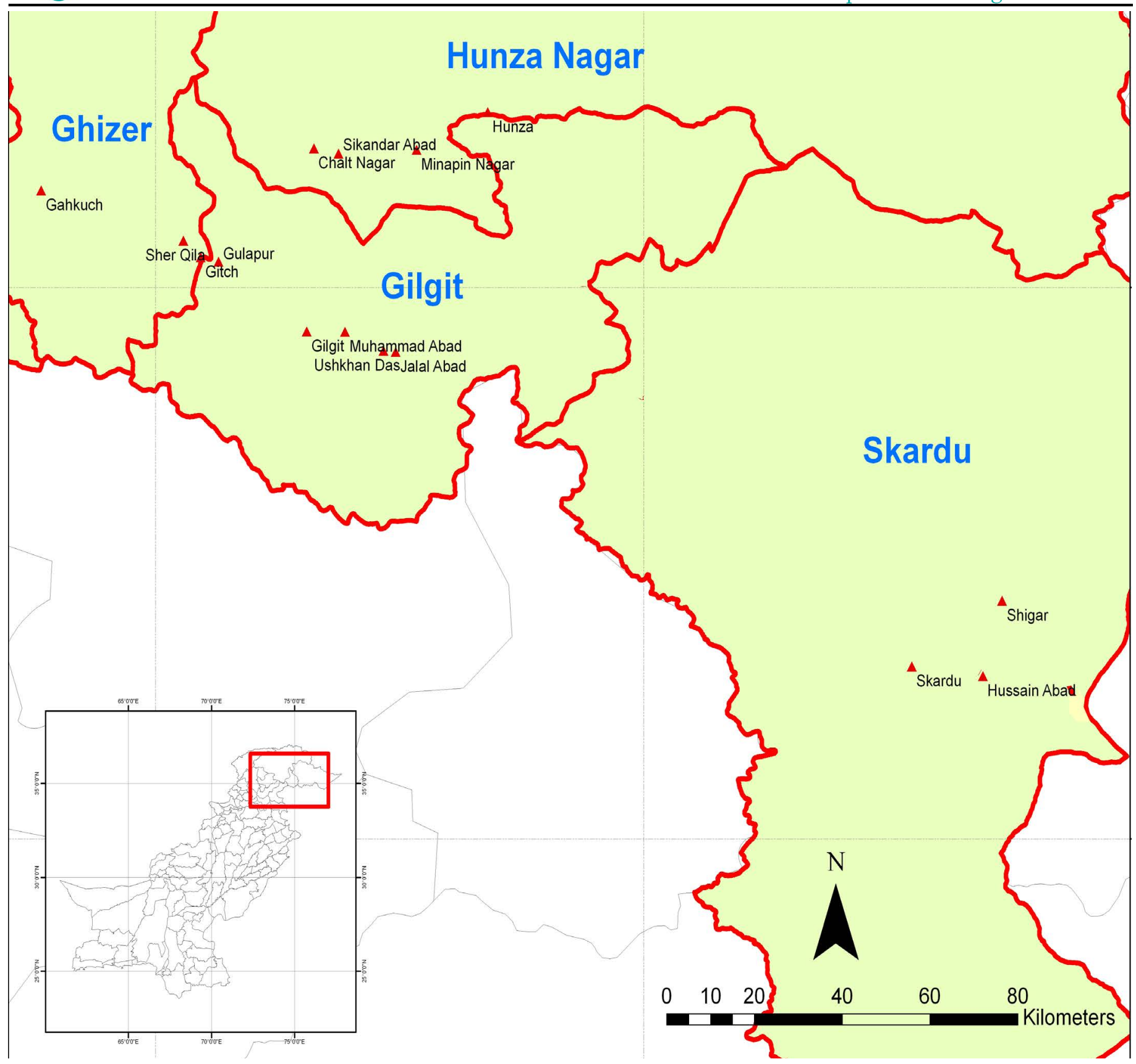

Figure 1: Collection localities of insect pollinators from Gilgit-Baltistan.

undoubtedly is single largest livelihood source. Most apricot cultivars in Gilgit-Baltistan blossom in early March and blossoming time is about fortnight and may be prolonged or shortened as a consequence of commonly prevailing stormy cold winter in the area due to extremely high mountains (Jasra and Rafi, 2003). Considerable variation is also seen in different cultivars in their blossoming time as well. Hence, all these factors effect pollination period which normally results in poor fruit set. A good synchronization between the activity period of the candidate pollinator and the flowering of the crop is very important. For fruit trees, with short seasonal flowering periods, univoltine pollinators with relatively short nesting periods are desirable, as they eliminate the need to provide alternative floral resources once the crop has been pollinated (Parker et al., 1987). Furthermore, farming community of the area is mostly unaware of the value of pollination for their fruits and vegetables and destroying pollinator population by demolishing their habitats and through excessive use of pesticides.

This study was designed to know biodiversity of insect pollinators from the apricot orchards in the area and dissemination of knowledge for farming communities as well as for general public regarding insect pollinators and their importance. Stanger et al. (1973) reported that some varieties of apricot were unable to produce large crop without cross-pollination. While some varieties had to be cross pollinated and others 
Table 1: Order, genera, family and species wise occurrence status.

\begin{tabular}{|c|c|c|c|c|}
\hline Order & Family & Genus & Species & Occurrence \\
\hline \multirow[t]{3}{*}{ 1.Diptera } & Syrphidae & Eristalis Latreille, 1804 & $\begin{array}{l}\text { Eristalis tenax Linnaeus, } 1758 \text { Eristalis arbustorum } \\
\text { Linnaeus, } 1758\end{array}$ & Previous $1^{\text {st }}-\mathrm{GB}$ \\
\hline & & Ischiodon Sack, 1913 & Ischiodon scutellaris, Fabricius, 1805 & $1^{\text {st }}-\mathrm{GB}$ \\
\hline & & Scaeva Fabricius, 1805 & Scaeva selenitica Meigen, 1822 & $1^{\text {st }}-\mathrm{Pak}(\mathrm{GB})$ \\
\hline \multirow[t]{9}{*}{ 2. Hymenoptera } & Apidae & Apis Linnaeus, 1767 & Apis mellifera Linnaeus, 1758 & Previous \\
\hline & & Bombus Latreille, 1802 & Bombus asiaticus Morawitz, 1875 & Previous \\
\hline & & Ceratina Latreille, 1805 & Ceratina viridissima, Dalla Torre, 1896 & $1^{\text {st }}-\mathrm{GB}$ \\
\hline & & Xylocopa Latreille, 1802 & $\begin{array}{l}\text { Xylocopa collaris, Lepeletier, } 1841 \text { Xylocopa acutipen- } \\
\text { nis Smith, } 1854 \text { Xylocopa dissimilis Lepeletier, } 1841\end{array}$ & $\begin{array}{l}1^{\text {st }} \mathrm{GB} 1^{\text {st }}-\mathrm{Pak} \\
\text { Previous }\end{array}$ \\
\hline & Halictidae & Lassioglossum Curtis, 1833 & Lassioglossum cerambyx Ebmer 1980 & $1^{\text {st }}-G B$ \\
\hline & Megachilidae & Osmia Panzer, 1806 & Osmia cornifrons 1887 & Previous \\
\hline & & Nomia Latreille, 1805 & Nomia westwoodi & $1^{\text {st }}-\mathrm{GB}$ \\
\hline & Vespidae & Vespa Linnaeus, 1758 & Vespa velutina, Lepeletier 1836 & Previous \\
\hline & & Vespula Thomson, 1869 & $\begin{array}{l}\text { Vespula flaviceps Smith, } 1870 \text { Vespula germanica } \\
\text { Fabricius } 1973\end{array}$ & $\begin{array}{l}1^{\text {st }}-\mathrm{GB} \text { Pre- } \\
\text { vious }\end{array}$ \\
\hline \multirow[t]{2}{*}{ 3. Lepidoptera } & Nymphalidae & Vanessa Fabricius & Vanessa cardui Linnaeus, 1758 & 1 st - GB \\
\hline & Papilionidae & Papilio Linnaeus & Papilio demoleus Linnaeus, 1758 & Previous \\
\hline (03) & (07) & $(14)$ & (18) & $\begin{array}{l}(08 \mathrm{~GB})(02 \mathrm{PK}) \\
(08 \text { Previous })\end{array}$ \\
\hline
\end{tabular}

GB: Gilgit Baltistan; PK: Pakistan, Previous: Previously recorded; Pak: Pakistan.

get benefit by cross-pollination (McGregor, 1976; Ahmad et al., 1986). Szabo et al. (1999) reported that fruit set and ripening period is improved by crosspollination. Pollination compatibility is an important factor affecting fruit set (Austin et al, 1996; McLaren and Fraser 1996; McLaren et al., 1996). According to Cruden (1972) altitudinal gradient affects the pollinators' activities, however, bees are most efficient at middle altitude.

\section{Materials and Methods}

Collection surveys were carried out during two consecutive years 2010 to 2011 in districts Gilgit, Ghizer, Hunza-Nagar and Skardu of GilgitBaltistan (Figure 1) to collect insect pollinators visiting apricot blossoms during early March. Random collection was done with the help of areal insect net, which can easily approach to the flowers. Identification of collected fauna was carried out with the help of microscope (Labomed CZM4$4 \mathrm{X}$ ) up to the possible taxonomic rank by running them through available literature and by comparing through reference collection at National Insect Museum (NIM), National Agriculture Research Center (NARC), Islamabad.

\section{Results and Discussion}

During study a total 18 species of 14 genera under seven families oforders Diptera,Hymenoptera andLepidoptera were identified (Table 1,2) as per following details.

\section{Order diptera}

Family syrphidae : Genus eristalis latreille, 1804 : Eristalis tenax linnaeus, 1758; Material examined: Hunza-Nagar: Sikandar Abad, 10ે, 26-iii-11, leg. Hina; Remarks: Earlier this species was reported by Shahzad et al., (2017) from Hunza, Astore, Gorikot, Sakardu and Murree. However, Arif (2001) reported this species from Faisalabad. Saleem et al. (2001) from Peshawar and Sajjad et al. (2010) from Multan; Distribution: Cosmopolitan except Antarctica and highest latitudes in the North (Metcalf, 1913), United States (Milne and Milne, 1980), India, Ceylon, Malaya Peninsula, Japan, China and Australia (Brunetti, 1923).

Eristalis arbustorum linnaeus, 1758: Material examined: Hunza-Nagar: Sikandar Abad, 1ठ, 26-iii11, leg. Hina; Remarks: First time recorded for GilgitBaltistan. This species was earlier reported by Brunetti (1923) from Azad Jammu and Kashmir and by Arif(2001) from Hazara, Mansehra and Abbotabad; Distribution: North Persia, Siberia, North Africa (Brunetti, 1923), Canada and United States (Anonymous, 2007). 
Table 2: Area wise distribution of species showing coordinates and remarks for localities in various districts of Gilgit-Baltistan.

$\begin{array}{ll}\text { Localities } & \text { Species } \\ \text { Gilgit } & \text { Hymenoptera Apis mellifera } \\ \text { Bombus asciaticus Xylocopa collaris } & \begin{array}{l}\text { Osmia cornifrons Lepidoptera Papilio } \\ \text { demoleus }\end{array}\end{array}$

Jalal Abad Hymenoptera Apis mellifera Lassioglossum cerambyx, Osmia cornifrons

Muhammad Hymenoptera Xylocopa collaris

Abad

Ushkhandas Hymenoptera Xylocopa collaris

Ghizer

\begin{tabular}{|c|c|}
\hline Gulapur & $\begin{array}{l}\text { Hymenoptera Bombus asciaticus } \\
\text { Lassioglossum cerambyx. Xylocopa } \\
\text { collaris X. dissimilis }\end{array}$ \\
\hline Gitch & $\begin{array}{l}\text { Hymenoptera Bombus asciaticus } \\
\text { Vespa velutina Xylocopa collaris X. } \\
\text { dissimilis }\end{array}$ \\
\hline Gahkuch & $\begin{array}{l}\text { Hymenoptera Bombus asciaticus } \\
\text { Osmia cornifrons. Vespula flaviceps } \\
\text { Vespula germanica Xylocopa collaris }\end{array}$ \\
\hline Sher Qila & $\begin{array}{l}\text { Hymenoptera Ceratina viridissima } \\
\text { Xylocopa collaris X.dissimilis Lepi- } \\
\text { doptera Vanessa cardui }\end{array}$ \\
\hline
\end{tabular}

\section{Hunza-Nagar}

Hunza

Chalt

Hymenoptera Bombus asciaticus

Osmia cornifrons

Lassioglossum sp. Osmia cornifrons

Xylocopa acutipennis

$\begin{array}{ll}\text { Minapin } & \text { Hymenoptera N. westwoodi. } \\ \text { Sikandar Abad } & \text { Diptera Eristalis. Arbustorum } \\ & \begin{array}{l}\text { E. tenax Ischiodon scutellaris } \\ \text { Scaeva selenitica }\end{array}\end{array}$

Skardu

Skardu

Hymenoptera Osmia cornifrons

35-17 74-14

$35-25 \quad 75-24$

Hussain Abad Hymenoptera Osmia cornifrons

Shigar
$36-17 \quad 74-36$

2323

36-07 $74014 \quad 2100$

\section{Lat.' Long.' Altit. M Remarks}

35-55 74-17 1473 A proper orchard along with other fruit trees i.e. cherry, apple, peach. Berseem was also cultivated.

1501 A complete orchard of apricot in a large area of Agriculture department

1473 Scattered trees along with Vegetables in a residential area.

1501 Residential area

1801 A large number of apricot trees along with almond trees scattered over hilly area along the river bank.

1801 A large number of apricot trees scattered over hilly area along the river bank.

1850 A huge hilly area covered with large number of fruit trees. Heavy flowering with cool and windy weather.

1801 Proper orchards with other fruit trees in a residential area. Trees were very old.

Scattered trees in hilly area as well in residential area, weather was really cold.

High fluctuation in weatherand topography of same area.Trees were cultivated in living houses and potato

fields but potato were not flourishing, at high altitude to river

2300 Big orchards, with heavy flowering, with other pome fruits.

35-17 74-14 $1960 \quad$ Hilly area, rough area.

Genus ischiodon sack, 1913: Ischiodon scutellaris, fabricius, 1805: Material examined: Hunza-Nagar: Sikandar Abad, 1ð̄, 26-iii-11, leg. Hina; Remarks: First time reported in Gilgit-Baltistan, however, earlier reported from Khyber Pakhtunkhwa: Balakot, Butkhela, Chakdara, Dir, Malakand, Peshawar, Swat; Islamabad; Punjab: Ghora gali, Multan, Mungawal, Khanewal, Murree (Alam et al., 1969; Sajjad and

Saeed, 2010; Sajjad et al., 2010; Ali et al., 2013; Shazad et al., 2017); Distribution: India, Northern Africa (Brunetti, 1923).

Genus scaeva fabricius, 1805: Scaeva selenitica meigen, 1822: Material examined: Hunza-Nagar: Sikandar Abad, 10̄, 2 ๆ, 26-iii-11, leg. Hina; Remarks: This species is reported first time from June 2020 | Volume 33 | Issue 2 | Page 205 
Pakistan; Distribution: Siberia, Europe (Dusek and Laska, 1985).

\section{Order bymenoptera}

Family apidae : Genus apis linnaeus, 1767 : Apis mellifera linnaeus, 1758 : Material examined: Gilgit: Jalal Abad, 3ㅇ, 18-iii-10, leg. Hina; Gilgit, 2ㅇ, 22iii-11, leg. Hina; Hunza-Nagar: Chalt, 1, 26-iii11, leg. Hina; Remarks: European origin species introduced in Pakistan. It was reported from Pakistan as a principal pollinator on cucumber (Sarwar et al., 2008), Sarson (Perveen et al., 2000), canola and black seed (Munawar et al., 2009); Distribution: Europe, Africa, Asia, North and South America, and Arctic Circle (Cocker, 2003).

Genus bombus latreille, 1802: Bombus asiaticus morawitz, 1875 : Material examined: Hunza-Nagar: Hunza, 19, 29-iii-10; leg. Hina; Ghizer: Gahkuch, 1ㅇ, 25-iii-11, leg. Hina; Gulapur, 2, 25-iii-11, leg. Hina; Gitch, 1ठ, 25-iii-11, leg. Hina; Chalt, $2 \hat{\jmath}$, 5ㅇ, 26-iii-11, leg. Hina; Skardu: Shigar, 4우 10iv-11, leg. Hina; Remarks: Earlier reported from Gilgit-Baltistan by Suhail et al. (2009). (Irshad et al., 2014) reported from Gilgit-Baltistan: Doarian, Darkot, Gilgit, Naltar, Hunza, Samgam, Pir Panjal and Sermik. It is well distributed species in GilgitBaltistan; Distribution: Hindu Kush (Reinig, 1940), Kashmir, Himalaya and Pir Panjal (Williams, 1991), Nepal, Mongolia, western and southwestern China, Pakistan, Afghanistan, Kazakhstan, Kyrghyzstan, Tajikstan, India (Gupta, 2010).

Genus ceratina latreille, 1805: Ceratina viridissima, dalla torre, 1896: Material examined: Ghizer: Sher Qila, 19, 22-iii-10, leg. Hina; Remarks: Earlier reported on alfalfa from Punjab (Ahmad, 1976); Peshawar (Bibi, 1984). However, previously reported on sunflower (Rahoo et al., 1985) and on mango inflorescence from Tandojam (Rehman et al., 1990). First time recorded from Gilgit-Baltistan; Distribution: India, China (Bingham, 1897), Sri Lanka (Wijesekara, 2001).

Genus xylocopa latreille, 1802: Xylocopa collaris, lepeletier, 1841 : Material examined: Gilgit: Ushkhandas, 19, 18-iii-10, leg. Hina; Muhammad Abad, 1, 20-iii-10, leg. Hina; Ghizer: Sher Qila,

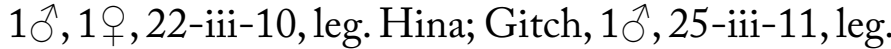
Hina; Gulapur, 1ठ,1, 25-iii-11,leg. Hina; Remarks: Earlier reported from Baluchistan: Naushki and Sind:
Karachi (Huda, 1975) from Peshawar (Bibi, 1984). This species was also reported from Sind on sunflower (Rahoo et al., 1985) and on cotton from Tandojam (Dhuyo et al., 1986). During this study this species was collected from apricot blossom from different localities of Gilgit-Baltistan i.e. Gilgit and Ghizer; Distribution: Reported from Ceylon (Sri Lanka) and India: Sikkim, Allahabad, Kumaun Malayan region to Siam (Bingham, 1897) Sri Lanka (Wijesekara, 2001) from Pakistan (Huda, 1975; Bibi, 1984; Rahoo et al., 1985; Dhuyo et al., 1986).

Xylocopa acutipennis smith, 1854: Material examined: Hunza-Nagar: Chalt, 1ㅇ, 26-iii-11, leg. Hina; Remarks: This is the first record from Pakistan; Distribution: India: Sikkim (Bingham, 1897; Gupta, 2010) while from India: Darjeeling, N. Khasi, Garo Hills; Myanmar: Dwana Hills, Southern Myanmar; Nepal: Kathmandu, Nayorkorte (Gupta, 2010).

Xylocopa dissimilis lepeletier, 1841: Material examined: Ghizer: Sher Qila, 2 9 , 22-iii-10,leg. Hina; Ghizer: Gulapur, 1ㅇ, 25-iii-11, leg. Hina; Skardu: Shigar, 4, 10-iv-11, leg. Hina; Remarks: Previously reported by Hussain et al. (2010) from District Skardu. (Irshad et al., 2014) reported it from Punjab: Faisalabad; Khyber-Pakhtunkhwa: Sindh: Sakrand; Gilgit-Baltistan: Skardu; Distribution: India; Sri Lanka; Myanmar (Bingham, 1897; Wijesekara, 2001) form India, China and Philipine (Gupta, 2010) from Pakistan (Hussain et al., 2010).

\section{Family balictidae}

Genus lassioglossum curtis, 1833: Lassioglossum cerambyx ebmer, 1980: Material examined: Gilgit: Jalal Abad, 1, 18-iii-10, leg. Hina; Ghizer: Gulapur, 2 , 25-iii-11,leg. Hina; Hunza-Nagar: Chalt, $59,26-$ iii-11, leg. Hina; Remarks: First time reported from Gilgit-Baltistan. However, Ascher and Rasmussen (2010) reported this species from Miandam (Swat); Distribution: Africa and Australia (Michener, 2007).

Genus nomia latreille, 1805: Nomia westwoodi gribodo 1894: Material examined: Gilgit: Jalal Abad, 2ㅇ, 18-iii-10, leg. Hina; Hunza-Nagar, Minapin Nagar, 1, 27-iii-11, leg. Hina; Remarks: This genus is first time recorded from Gilgit-Baltistan. Previously this species was reported by Bibi (1984) from Peshawar. (Irshad et al., 2014) reported from Punjab: Murree; Distribution: Asia, Australia, Africa, America (Michener, 2007). 
Family megachilidae: Genus osmia panzer, 1806: Osmia cornifrons radoszkowski 1887: Material examined: Gilgit: Jalal Abad, 3우 18-iii-10, leg. Hina; Ghizer: Gahkuch, 4우 22-iii-10, leg. Hina; Hunza-Nagar: Hunza, 79, 29-iii-10, leg. Hina; Chalt, 1ठ, 39 26-iii-11, leg. Hina; Skardu: Skardu 1ð 4ㅇ, 08-iv-11, leg. Hina; Skardu: Shigar 5ㅇ, 10-iv-11, leg. Hina; Remarks: Osmia cornifrons has been reported by Hussain et al. (2010) from Skardu; Distribution: Europe, Southwestern Asia, North America (Michener, 2007).

\section{Family vespidae}

Genus vespa linnaeus, 1758: Vespa velutina (Lepeletier, 1836): Material examined: HunzaNagar: Chalt, 2q, 26-iii-11, leg. Hina; Remarks: This species have been reported from GilgitBaltistan: Diamar, Chilas Hunza-Nagar, Ghizer, Gilgit, Skardu and Nomal; Khyber-Pakhtunkhwa: Chitral, Swat, Charbagh, Shangla, Battagram, Abbottabad, Havelian, Mansehra, Lower and Upper Dir, Shougran, Garihabibullah, Jaba, Abbottabad, Nathia gali; Islamabad; Punjab: Murree, Rawalpindi, Jhelum, Attock and Chakwal; Azad Jummu and Kashmir: Rawalakot, Pir Chinasi, Hajira, Topa, Thorar and Mandhol (Dvořák, 2007; Mahmood et al., 2012; Siddiqui et al., 2015; Faiz et al., 2016, Khan et al., 2017; Rafi et al., 2017; Rauf et al., 2018); Distribution: China; Bhutan; Afghanistan; India; Malaysia; Indonesia; Laos; Myanmar; Nepal; Pakistan; Vietnam; Taiwan; Thailand; introduced into Belgium; Tsushima; Korea; France; Italy; Portugal; Spain; Yemen (Carpenter and Kojima, 1997; Dvořák, 2007; Mahmood et al., 2012).

Genus vespula thomson, 1869: Vespula flaviceps (Smith, 1870): Material examined: Ghizer: Gahkuch, 19, 25-iii-11, leg. Hina; Remarks: Earlier reported this species from Khyber-Pakhtunkhwa: Nathia Gali, Swat, Batgram; Punjab: Murree (Dvořák, 2007; Mahmood et al.,2012; Rafi et al.,2017); Distribution: China; Nepal; Pakistan; Korea; Laos; India; Japan; Myanmar; Taiwan; Russia; Thailand (Carpenter and Kojima, 1997; Dvoŕák, 2007; Mahmood et al., 2012).

Vespula germanica (Fabricius, 1973): Material examined: Ghizer: Gahkuch, 19, 25-iii-11, leg. Hina; Skardu: Hussain Abad, 1 9 , 25-iv-11, leg. Hina; Remarks: Earlier reported this species from GilgitBaltistan: Ghizer, Skardu, Gilgit, Daimer, Khyber, Chillas, Gulmit, Khuramabad, Shish kot, Passu,
Gulkin, Aliabad, Nagar, Denor, Sost, Misger; Khyber-

Pakhtunkhwa: Chitral, Havelian, Ayubia, Bamboret valley, Brun, Lower and Upper Dir, Abbottabad, Mansehra, Balakot, Baffa Swat and Kalam; Punjab: Rawalpindi, Baluchistan: Ziarat, Kalat (Chaudhry et al., 1966; Dvořák, 2007; Mahmood et al., 2012; Faiz et al., 2016; Rafi et al., 2017; Rauf et al., 2018);

Distribution: Austria; Belgium; India; Kazakhstan; Azores; Armenia; Algeria; Belarus; Albania; Bulgaria; Canada; Poland; Portugal; China; Netherlands; Pakistan; Croatia; England; France; Germany; Israel; Iran; Korea; Czech Republic; Denmark; Gerogia; Greece; Hungary; Ireland; Morocco; Mongolia; Luxembourg; Malta; Syria; Taiwan; Tajikistan; Norway; Russia; Scotland; Slovenia; Sweden; Switzerland; Spain; Romania; Turkey; Ukraine; Turkmenistan; Tunisia; Uzbekistan and U.K.; introduced into Ascension Island; Argentina; Australia; Canada; South Africa; New Zealand; Chile; Iceland; U. S. A. (Carpenter and Kojima, 1997; Dvořák, 2007; Mahmood et al., 2012).

\section{Order lepidoptera}

Family nymphalidae: Genus vanessa fabricius: Vanessa cardui linnaeus, 1758: Material examined: Ghizer: Sher Qila, 1, 22-iii-10, leg. Hina; Remarks: First time collected from district Ghizer. However already known from different localities i.e. Karachi (Swinhoe, 1887; Malik, 1970), Chitral (Leslie and Evans, 1903), Lahore (Ahsan and Iqbal, 1975), Harni (Balochistan) (Malik, 1970), Rawalpindi and Islamabad (Hasan, 1994; Iqbal, 1978), Gilgit by Hasan (1997). Recently reported from Buner (Naz, 2000) and Azad Jammu and Kashmir (Khan et al, 2008); Distribution: Throughout world except South America, Arctica and Antarctica. (Hasan, 1994).

\section{Family papilionidae}

Genus papilio Linnaeus: Papilio demoleus linnaeus, 1758: Material examined: Gilgit: Gilgit, 1 ㅇ, 22-0311,leg. Hina; Remarks: Widely distributed in Pakistan e.g. Karachi (Swinhoe, 1887; Malik, 1970), Chitral (Lesilie and Evans, 1903), Lahore (Ahsan and Iqbal, 1975; Philipe and Rhe, 1917; Puri, 1931), Peshawar, Hazara, Haripur, Trarkhel, Mirpur (Chaudhry et al, 1970), Rawalpindi and Islamabad and Murree hills (Hasan, 1994; Iqbal, 1978), and Gilgit (Hasan, 1997). Recently collected from Buner (Naz, 2000), Swat, Kohat (Rafi et al., 2000) and Azad Jammu and Kashmir (Khan et al., 2008); Distribution: Australia, Papua New Guinea, Pakistan, Nepal, Sri Lanka, 
India, Japan, China, Taiwan, Kampuchea, Malaysia, Thailand, Laos, Vietnam, Iran, Afghanistan, Qatar, Bahrain, Kuwait, Saudi Arabia, Myanmar, United Arab Emirates (Rafi et al., 2000).

From biodiversity point of view there are two hot spots in the Himalaya; first is eastern Himalaya and second is western Himalaya (occur in Galigit Baltistan).

During surveys 18 species of 14 genera belonging to 07 families and 03 orders were recorded. Order Diptera was represented by only one family Syrphidae. Four families: Apidae, Halictidae, Megachilidae, and Vespidae were recorded from order Hymenoptera and from order Lepidoptera two (2) families: Nymphalidae and Papilionidae were reported. Of the 18 species collected and studied during the surveys, 02 were first time reported in Pakistan, 08 were first time reported in Gilgit Baltistan and the remaining 08 were previously reported in Pakistan (Table 1).

In family Syrphidae three (3) genera were recorded. From genus Eristalis two species namely; E. tenax and E. arbustorum were identified later was new record for Gilgit-Baltistan. One species Ischiodon scutellaris of genus Ischiodon and one species Scaeva selenitica of genus Scaeva were also collected. I. scutellaris was first time reported from GB, while genus Scaeva and its species Scaeva selenitica were new records for GilgitBaltistan area as well as for the country.

From Hymenoptera under genus Osmia two species were collected under family Megachilidae, while, family Apidae resulted into four genera. Only one species Ceratina viridissima was represented in genus Ceratina, this species is also a new record for this area. Genus Xylocopa contains three species i.e. $X$. collaris, $X$. acutipennis and $X$. dissimilis, out of these $X$. acutipennis is newly recorded species from Pakistan. In genus Apis and Bombus single species Apis mellifera and Bombus asciaticus were identified respectively. There were two unidentified species in each genera Nomia and Lassioglossum under Halictidae. Genus Nomia was first time reported from that area. The other unidentified species of Lassioglossum was also first confirm record for the area.

Two genera were recorded in family Vespidae i.e. Vespa and Vespula. These were very rare. Genus Vespa represented by one species $V$. velutina, which is widely reported from Gilgit Baltistan, Khyber
Pakhtoonkhwa and Azad Jammun Kashmir areas. Genus Vespula resulted into two species which were Vespula germanica and $V$. Alaviceps, later was new record for Gilgit-Baltistan. Under Lepidoptera Vanessa cardui (Nymphalidae) and Papilio demoleus (Papilionidae) were reported and the former is new record for Gilgit Baltistan area.

However, in the Gilgit Baltistan area most of apricot cultivars blossom in early March. Honeybees were the most abundant on apricot flowers (55\%) followed by wasp (13\%) and bumble bees and butterflies (i.e. $8 \%$ each). Few respondents did report the activity of birds like sparrows on apricot flowers as well.

Different kinds of insect pollinators such as bees, flies, beetles, butterflies, moths and wasps are important pollinators of many crops (Partab, 2003). It has been estimated that over three quarters of the world's crops and over 80 percent of all flowering plants depend on animal pollinators especially bees (Kenmore and Krell, 1998). In two recent studies Iqbal et al. (2016) reported ten species of wild bees as active pollinators of almond and Aslam et al. (2017) explored 15 species of non-apis bees from Potohar region.

It is concluded from above results that total number of specimens were 232 but except nine specimens all other were bees. So it can be concluded that bees are the top most pollinators of apricot in Gilgit-Baltistan, but as in the vicinity of apricot plants several other fruiting plants and crops were also grown that may have caused the presence of some other insect species such as dipterous flies, wasps and butterflies.

From this study it is concluded that from the localities: Gahkuch, Gulapur and Chalt most diverse species with high population has been collected, which have moderate altitudes. According to Cruden (1972) altitudinal gradient affects the pollinators' activities, and bees are most efficient at middle altitude.

\section{Author's Contribution}

Hina Maryam: Conceptualization, introduction and methodology.

Muhammad Ather Rafi: Study design and technical input at every step.

Ahmed Zia: Data collection, entry and literature review.

Ghulam Rasul: Data screening and analysis. 
Muhammad Kamal Sheikh: Tabulation design framework and overall management.

Muhammad Qasim: Abstract and referencing.

Gulnaz Perveen: Write up, results \& discussion and conclusions.

\section{References}

Ahmad, R. 1976. A note on insect pollinators of alfalfa in Pakistan. N.Z. Entomol. 6(2). https:// doi.org/10.1080/00779962.1976.9722243

Ahmad, R., N. Muzaffar, S.M.A. Makhdomi and S. Khan. 1986. Honeybee research programme, progress report. 1977-85. Pak. Agric. Res. Counc. Islamabad, Pak. p. 172.

Ahsan, M. and J. Iqbal. 1975. A contribution to butterflies of Lahore with the addition of new records. Bilogia. 21(2): 143-158. Anonymous.

Alam, M.M., M.N. Beg, R.A. Syed and S. Shah. 1969. Survey of parasites of insect pests of cultivated and useful plants and survey of insect destroying weeds and their parasites. Final Rep., Pak. Stat., Commonw. Inst. Biol. Control. pp.243.

Ali, S., A. Shehzad, M.A. Rafi and S.A. Zia. 2013. Insect pollinators of litchi (Litchi chinensis) from district Haripur, Pakistan. Pak. J. Agric. Res. 26(3): 161-170.

Anonymous, 2007. http://zipcodezoo.com/ Animals/E/Eristalis_arbustorum

Arif, M.J. 2001. Taxonomic studies of syrphidae (Diptera) of Pakistan. M.Sc Thesis. Univ. Agric. Faisalabad, Pak.

Ascher, J.S. and C. Rasmussen. 2010. Report: The bee fauna and pollination in Pakistan. FAO. pp. 59.

Aslam, A., M.A. Rafi and A. Zia. 2017. Non-Apis bees of family Apidae (Hymenoptera) from Potohar region of Pakistan. J. Entomol. Zool. Stud. p.12.

Austin, P., E.W. Hewett, D.A. Noiton and J.A. Plummer. 1996. Cross pollination of 'Sun drop' apricot (Prunus armeniaca L.) by honeybees. N.Z. J. Crop Hortic. Sci. 24: 287-294. https:// doi.org/10.1080/01140671.1996.9513963

Bendif, H., R. Benmehia, F. Bahlouli, S. Tellache, A. Slamani and Z. Zedam. 2017. Contribution to the study of some aspects of pollination in six varieties of apricot in the region of M'sila (Algeria).J. Sci.Agric. 2017, 1:347-351.https:// doi.org/10.25081/jsa.2017.v1.886

Bibi, S. 1984. Non-apis bees of Peshawar. Unpublished M.Sc Thesis. Zool. Dep., Univ. Peshawar, Pak.

Bingham, C.T.1897. Hymenoptera. wasps and bees. In: W.T. Blandford (Ed.), The fauna of British India, including Ceylon and Burma. Taylor and Francis, London. 1: pp. 579.

Brunetti, E. 1923. Diptera, brachycera. The fauna of British India (including Ceylon and Burma). Taylor and Francis, London. Vol. 2: pp. 424.

Carpenter, J.M. and J.I. Kojima. 1997. Checklist of the species in the subfamily Vespinae (Insecta: Hymenoptera: Vespidae). Nat. Hist. Bull. Ibaraki Univ. 1: 51-92.

Chaudhry, G., M.I. Chaudhry and N.K. Malik. 1970. Survey of insect fauna of forests of Pakistan. Vol. II. Pak. For. Inst. Peshawar.

Chaudhry, G.U., M.I. Chaudhry and S.M. Khan. 1966. Survey of Insect fauna of forests of Pakistan. Pak. For. Inst. Peshawer. pp. 167.

Cocker, K. 2003. the biogeography of the honeybee (Apis mellifera) San Francisco Univ. Geog. 316: Biogeogr.

Cruden, R.W. 1972. Pollinators in high elevation ecosystem: Relative effectiveness of bird and bees. Sci. 176: 1439-1440. https://doi. org/10.1126/science.176.4042.1439

Dhuyo, A.R., G.H. Munshi, S.M.S.H. Naqvi, S.N.H. Rizvi, A. Rustamani. 1986. Insect pollinator complex of cotton crop, Gossipium birsutum. Pak. Cottons. 30 (3): 45-47.

Dusek, J. and P. Laska. 1985. A review of the genus Scaeva Fabricius (Diptera, Syrphidae) with the description of a new species from Chile. Acta. Ent. Bohemoslov. 82: 206-228.

Dvořák, L. 2007. The social wasp fauna of Pakistan (Hymenoptera, Vespidae). Linzer Biol. Beitr. 39(1): 51-55.

Faiz, A., M.A. Rafi, A. Zia, A. Shah, S.W. Shah, R.U. Khan and M. Saeed. 2016. Wasp fauna of (Eumeninae: Vespinae and Polistinae) in forests of Gilgit-Baltistan (Pakistan). Pure Appl. Biol. 5(4), p. 7. https://doi.org/10.19045/ bspab.2016.50073

Gupta, R.K. 2010. An annotated catalogue of bee species of Indian region.

Hasan, S.A. 1997. Biogeography and diversity of butterflies of North West Himalaya. In S.A. Mufti; C.A. Woods; S.A. Hasan (Ed) Biodiversity of Pakistan. Museum Nat. Hist., 
Islamabad. pp. 537.

Hasan, S.A. 1994. Butterflies of Islamabad and the Murree Hills. Asian Study group, Islamabad. pp. 68.

Huda A.I. 1975. Some new records of species of genus Xylocopa based on the collections in the Zoological Survey of Pakistan. Agric. Pak. 1975. 26(2): 213-218.

Hussain, A., M.R. Khan, A. Tamkeen, T. Anwar, S. Tahir and I. Ahmad. 2010. Distributional diversity of hymenopterans pollinator bees from district Skardu, Northern areas of Pakistan. Pak. J. Ento. Karachi. 25 (2): 81-86.

Iqbal, J. 1978. A preliminary report on butterflies of District Rawalpindi and Islamabad. Biologia. 24 (2): 237-247.

Iqbal, Z., M.A. Rafi, A. Shehzad, A. Haq, A. Zia, A. Bhatti and S.W. Shah. 2016. Wild bees' fauna associated with almond plantation in northern Pakistan. Pak. J. Entomol. 31(1): 117-125.

Irshad, M., E. Stephen M.A. Rafi and A. Shehzad. 2014. Diversity of bees of Pakistan with notes on their morphology, biology and conservation. NIM/DPEP, NARC, Pak. Agric. Res. Counc. / UNEP-GEF-FAO. pp. 65.

Jasra, A.W. and M.A. Rafi.2003. Cash crop farming in the northern Pakistan: The importance of pollinator diversity and managed pollination in apricots. Int. Centre Integr. Mt. Dev. (ICIMOD) Kathmandu, Nepal. p. 60.

Kenmore, P. and R. Krell. 1998. Global perspectives on pollination in agricultural and agro ecosystem management. Int. Workshop Conserv. Sustainable use Pollinators Agric. Emphasis Bees. October 7-9, 1998 Sao Paulo, Brazile.

Khan, A.K., M.R. Khan, M.A. Rafi and M. Qasim. 2017. Wasp fauna of (Eumeninae, vespinae and polistinae) of district Poonch, Azad Jammu and Kashmir (Pakistan). J. Entomol. Zool. Stud. 5(6): 1587-1590.

Khan, M.R., M. Irshad and M.A. Rafi. 2008. Insect fauna of Azad Jammu and Kashmir. MK traders, Islamabad, Pakistan. pp. 143.

Klein, M.A., B.E. Vaissière, H.C.I. James, S.A. Cunningham, C. Kremen and T. Tscharntke. 2007. Importance of pollinators in changing landscapes for world crops. Proc. Biol. Sci. 274: 303-313. https://doi.org/10.1098/ rspb.2006.3721

Leslie, G.A. and W.H. Evans. 1903. The butterflies of Chitral. J. Bombay. Nat. Hist. Soc. Vol. XIV. pp. 666.

Mahmood, K., M. Ullah, A. Aziz, S.A. Hasan and M. Inayatullah. 2012. To the knowledge of Vespidae (Hymenoptera) of Pakistan. Zootaxa. 3318: 26-50. https://doi.org/10.11646/ zootaxa.3318.1.2

Malik, J.M. 1970. Notes on the butterflies Pakistan in the collection of Zoological survey department, Karachi. Part 1. Rec. Zool. Sur. Pak. 2 (2): 25-54.

McGregor, S.E. 1976. Insect pollination of cultivated crop plants. USDA. Agric. Handbook No. 496: pp. 411.

Mclaren, G.F., R.J.A. Frase. 1996. Pollination compatibility of 'Sundrop' apricot and its progeny in the 'Clutha' series. N.Z. J. Crop Hortic. Sci. 24: 47-53. https://doi.org/10.1080/ 01140671.1996 .9513934

Mclaren, G.F., FR.J.A. Rase and J.E. Grant. 1996. Some factors influencing fruit set in 'Sundrop' apricot. N.Z. J. Crop Hortic. Sci. 24: 55-63. https://doi.org/10.1080/01140671.1996.95139 35

Metcalf, C.L. 1913. The syrphidae of Ohio. Ohio State Univ. Bull. 17: 1-123.

Michener, C.D. 2007. The bees of world [second edition]. Baltimore: Johns Hopkins Univ. Press. pp. 992.

Milne, L. and M. Milne. 1980. The Audubon society field guide to North American insects and spiders. Alfred A. Knopf, Inc., New York, NY.

Munawar, M.S., G. Sarwar, S. Raja, E. Stephen, F. Iftikhar and R. Mahmood. 2009. Pollination by honeybee (Apis mellifera) increases seed setting and yield in black seed (Nigella sativa). Int. J. Agric. Biol. 5: 611-615.

Naz, F. 2000. Distribution and taxonomy of butterflies of District Buner. M.Sc thesis. NWFP Agric. Univ., Peshawar, Pak. pp. 92.

Ollerton. J. 1999. The evolution of pollinator-plant relationship within the arthropods. (Evolution and phylogeny of arthropoda). Bol. S.E.A. 26: 741-758

Partab,U.2003. Cash crop farming in the Himalayas: The importance of pollinator management and managed pollination. 226-246. In: "Biodiversity and the Ecosystem Approaches in Agriculture, Forestry and Fisheries" FAO Proce. Room 1213 October 2002. pp.311.

Parker, F.D., S.W.T. Batra and V.J. Tepedino. 1987. 
New pollinators for our crops. Agric. Zool. Rev. 2: 279-304.

Perveen, N., M. Alhariri, M. Ahmad and A. Suhail. 2000. Insecticidal mortality, foraging behaviour and pollination role of honeybee (Apis mellifera L.) on sarson (Brassica campestris L.) crop. Dep. Agric. Entomol., Univ. Agric., Faisalabad, Pak. 38040.

Philipe, W.V. and D. Rhe. 1917. The butterflies of Lahore. J. Bombay. Nat. His. Soc. 25: 136-142.

Puri, D.R. 1931. Butterflies of Lahore. Govt. College Lahore. pp.61.

Rafi, M.A., J.M. Carpenter, M. Qasim, A. Shehzad, A. Zia, M.R. Khan, M.I. Mastoi, F. Naz, M. Ilyas, M. Shah and A.R. Bhatti. 2017. The vespid fauna of Pakistan. Zootaxa. 4362 (1): 001-028. https://doi.org/10.11646/zootaxa.4362.1.1

Rafi, M.A., M.R. Khan and M. Irshad. 2000. Papilionid (Swallowtails) butterflies of Pakistan. Gul Awan printers, Islamabad, Pak. p. 33.

Rahoo, G.M., M.K. Lohar, G.H. Munshi, and S.M. Nizamani. 1985. The insect pollinators of sunflower, Helianthus annuus L. in Sindh, Pakistan. Pak. J. Agric. Agric. Eng. Vet. Sci. 1(24): 79-80.

Rauf, S.A., M.A. Rafi, M. Qasim, M.K. Sheikh, K. Mehmood, S. Durrani, A. Khan and A. Rahman. 2018. Wasp fauna of subfamilies (Eumeninae, Polistinae and Vespinae) from Dir, KPK, Pakistan. Univ. Sindh J. Anim. Sci. 2(1): $1-7$.

Rehman, K., T. Husain, A.H. Soomro and R.D. Khuhro.1990. Pollinators activity on mango inflorescence. Proc. 10 ${ }^{\text {th }}$ Cong. Zool. 143-146.

Reinig, W.F. 1940. Beitragzur kenntnis der hummelfauna von Afghanistan. (Hym., Apid.). (Ergibnisse der Reise von H. und E. Kotzsch in den Hindukusch im Jahre 1936.) Deutsch Entomol. Z. 224-235. https://doi.org/10.1002/ mmnd.48019390109

Sajjad, A. and S. Saeed. 2010. Floral host plant range of Syrphid flies (Syrphidae: Diptera) under natural conditions in Southern Punjab, Pakistan. Pak. J. Bot. 42(2): 1187-1200.

Sajjad, A., S. Saeed and M. Ashfaq. 2010. Seasonal variation in abundance and composition of hoverfly (Diptera: Syrphidae) communities in Multan, Pakistan. Pakistan. J. Zool. vol. 42(2):
$105-115$.

Saleem, M., M.J. Arif and A. Suhail. 2001. Taxonomic studies of Syrphidae of PeshawarPakistan. Int. J. Agric. Biol. 533-534.

Sarwar, G., M. Aslam, M.S. Munawar, S. Raja and R. Mahmood. 2008. Effect of honeybee (Apis mellifera) pollination on fruit setting and yield of cucumber (Cucumis sativus L). Honeybee Res. Inst., Nat. Agric. Res. Center, Islamabad. Pakistan. Pak. Entomol. Vol. 30, No. 2.

Shahzad, A., K. Ghorpade, M.A. Rafi, A. Zia, A.R. Bhatti and S.W. Shah. 2017. Faunistic study of hover flies (Diptera: Syrphidae) of Pakistan". Orient. Insects.1-24. https://doi.org/10.1080/0 0305316.2016.1274275

Siddiqui, J.A., I. Bodlah, J.M. Carpenter, M. Naeem, M. Ahmad and M.A. Bodlah. 2015. Vespidae (Hymenoptera) of the Pothwar region of Punjab, Pakistan.Zootaxa. 3914(5): 501-524. https://doi.org/10.11646/zootaxa.3914.5.1

Stanger, W., R. Thorp and L. Foote. 1973. Honeybee pollination in California. Div. Agric. Sci. Univ. Calif. Leaflet 75-LE. p. 9.

Suhail, A., A.M. Sabir, M. Asghar, M.A. Rafi and A. Qadir. 2009. Geographic distributional patterns of the genus Bombus (Bombini: Apidae: Hymenoptera) in northern Pakistan. Biol. Divers. Conserv. Bio. Di. Con. 2/1. 1-9.

Swinhoe, C. 1887. On the Lepidoptera of Karachi and its neighbourhood. Part 1. J. Bombay. Nat. Hist. Soc. Vol. II. 29-280.

Szabo, Z., J. Nyeki, A. Andrasfalvy, L. Szalay, A. Pedryc and I. Karayiannis. 1999. Evaluation of some Romanian apricot varieties in Hungary. Proceedings of the XIth international symposium on apricot culture, veria-makedonia, Greece, 25-30 May, 1997, Acta. Hortic. 1 (488): 211-214. https://doi.org/10.17660/ ActaHortic.1999.488.31

Wijesekara, A. 2001. An annotated list of bees (Hymenoptera: Apoidea: Apiformes) of Sri Lanka. Tijd. Entomol. 144: 145-157. https:// doi.org/10.1163/22119434-99900063

Williams, P.H. 1991. The bumble bees of the Kashmir Himalaya (Hymenoptera: Apidae: Bombini) Bull. Brit. Nat. Hist. Museum, 60(1): pp. 204. 